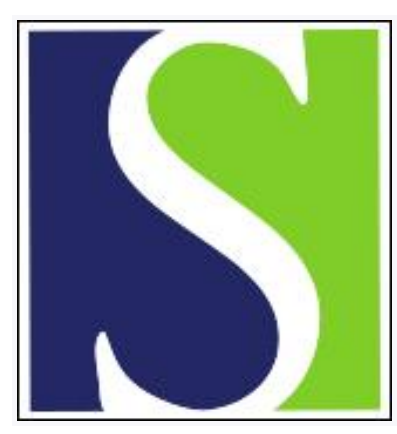

Scand J Work Environ Health 1977;3(1):32-35

https://doi.org/10.5271/sjweh.2793

Issue date: Mar 1977

\title{
Mercury in human amniotic fluid.
}

by Suzuki T, Takemoto T-I, Shishido S, Kani K

Key terms: amniotic fluid; human amniotic fluid; inorganic mercury; mercury; organic mercury; pregnant woman; woman; women

This article in PubMed: www.ncbi.nlm.nih.gov/pubmed/847429

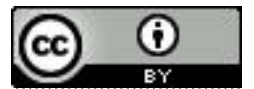




\title{
Mercury in human amniotic fluid
}

\author{
by TSUGUYOSHI SUZUKI, TAI-ICHIRO TAKEMOTO, SACHIKO SHISHIDO \\ and KAZUMI KANI ${ }^{1}$
}

\begin{abstract}
SUZUKI, T., TAKEMOTO, T., SHISHIDO, S. and KANI, K. Mercury in human amniotic fluid. Scand. j. work environ. \& health 3 (1977) $32-35$. The levels of inorganic and organic mercury in human amniotic fluid were examined in 57 Japanese pregnant women with a gestational age of 4 months to term. Inorganic mercury was detected in all but two samples, while organic mercury was found in only 30 women. The level of inorganic mercury was higher than organic mercury. The highest levels of both inorganic and organic mercury were observed in the seventh month of gestation.
\end{abstract}

Key words: amniotic fluid, inorganic mercury, mercury, organic mercury, pregnant woman.

Studies on the metabolism of mercury in the fetoplacental complex are urgently needed in view of the fact that fetal brain may have an increased susceptibility to methylmercury. In animal experiments methylmercury anō elemental mercury cross the placenta freely, while inorganic mercury compounds accumulate in the placenta $(2,3,7,11)$.

In humans who consume a considerable amount of marine fish, most of the daily intake of mercury is in the form of methylmercury. Human fetal erythrocytes contain about $30 \%$ more mercury than maternal erythrocytes in Swedish and Japanese fisheating populations and in Iraqi women poisoned by methylmercury-contaminated bread $(1,12,13)$. In humans, the placental accumulation of mercury is greater than the accumulation in maternal and fetal blood $(12,14)$.

\footnotetext{
1 Department of Public Health, Tohoku University School of Medicine, Sendai, Japan, and Department of Obstetrics and Gynecology, Showa University, Tokyo, Japan.
}

Reprint requests to: Dr. Tsuguyoshi Suzuki, Department of Public Health, Tohoku University School of Medicine, Seiryocho 2-1, Sendai, 980 Japan.
In this context, if complications due to amniocentesis can be avoided, it is reasonable, and of interest, to measure mercury levels in amniotic fluid during the normal progress of gestation.

Amniotic fluid sampled at the time of delivery contained about $15.0 \mathrm{n} \mathrm{mol} \mathrm{Hg} / \mathrm{l}$ in Norwegian women (14), and a single value of mercury in amniotic fluid observed in the Iraqi epidemic of methylmercury poisoning represented $2 \%$ of the whole blood value (1). Total mercury was measured in these two studies. Because of the different pharmacokinetic properties of mercury according to type of compound, separate measurements of inorganic and organic mercury would add to the understanding of the behavior of mercury in the fetoplacental complex.

\section{MATERIALS AND METHODS}

Fifty-seven women with a gestational age of 4 months to term were sampled for this study. Women in the early or middle period of pregnancy (4 to 7 months) were undergoing a termination of pregnancy for various reasons. The problem of complications due to amniocentesis was mini- 
mized in these women. There were 8 women with mild or moderate toxemia ( 1 in 7 months' gestation, 2 in 8,1 in 9 and 4 in 10 months or over). The severity of toxemia was judged by the level of systolic blood pressure, proteinuria and edema.

The amniotic fluid was sampled mostly by transabdominal amniocentesis after the placental localization and fetal parts had been identified with the ultrasonic method. In several cases transcervical amniocentesis was applied at the time of delivery, and in a few cases of Cesarean section the amniotic fluid was obtained by direct puncture through the wall of the uterus.

Inorganic and organic mercury were measured separately by the method of Magos (6). The absolute sensitivity of mercury measurements by this method is 2.5 pmol for both chemical forms of mercury in our laboratory. The volume of amniotic fluid used for measurement was $4 \mathrm{ml}$; the detection limit was about $0.5 \mathrm{n}$ $\mathrm{mol} / \mathrm{l}$.

Amniotic fluid proteins were measured by the biuret method, and creatinine was colorimetrically measured with the use of alkali-picrate.

\section{RESULTS}

Only one amniotic fluid sample did not contain a detectable amount of mercury (table 1). Inorganic mercury was detected in all but two samples, while organic mercury was found in only 30 out of 57 women. The mercury level was clearly higher in the inorganic than in the organic form ( $p<0.005$, by $\chi$-statistic), but the level of inorganic mercury significantly correlated with that of organic mercury $(\mathrm{r}=0.852, \mathrm{p}<0.01)$.

The mercury level changed according to gestational age $(p<0.01$ for inorganic mercury, $\mathrm{p}<0.005$ for organic mercury by $\mathrm{F}$-statistic; one-way analysis of variance in terms of gestational months). The highest value of both inorganic and organic mercury was observed in the seventh month of gestation. Mercury levels, once elevated in this gestational month, decreased in the eighth month of gestation.

There was a progressive increase in the creatinine concentration from the seventh month of gestation until term, but the protein level did not change significantly (table 2).

Cases of toxemia did not show any significant deviation from those of normal pregnancy in terms of concentrations of mercury, creatinine, and proteins, except for one case in the eighth month of gestation, in which organic mercury, total mercury and protein concentrations were far greater than those in normal pregnancy at the same gestational age.

Table 1. Mercury concentrations in amniotic fluid.

\begin{tabular}{|c|c|c|c|c|c|c|c|c|c|c|}
\hline \multirow{2}{*}{$\begin{array}{l}\text { Gestation } \\
\text { (months) }\end{array}$} & \multirow[t]{2}{*}{ Number } & \multicolumn{3}{|c|}{$\begin{array}{l}\text { Inorganic mercury } \\
\text { (n mol } \mathrm{Hg} / \mathrm{l})\end{array}$} & \multicolumn{3}{|c|}{$\begin{array}{l}\text { Organic mercury } \\
\text { (n mol } \mathrm{Hg} / \mathrm{l} \text { ) }\end{array}$} & \multicolumn{3}{|c|}{$\begin{array}{l}\text { Total mercury b } \\
\text { (n mol Hg/l) }\end{array}$} \\
\hline & & Mean & $\mathrm{SD}$ & $\begin{array}{l}\text { Unde- } \\
\text { tected a }\end{array}$ & Mean & $\mathrm{SD}$ & $\begin{array}{l}\text { Unde- } \\
\text { tected a }\end{array}$ & Mean & SD & $\begin{array}{l}\text { Unde- } \\
\text { tected a }\end{array}$ \\
\hline 4 & 3 & 3.0 & 2.0 & 0 & 1.5 & 2.0 & 1 & 4.5 & 2.5 & 0 \\
\hline 5 & 7 & 6.0 & 8.5 & 0 & 1.5 & 2.5 & 4 & 7.5 & 11.0 & 0 \\
\hline 6 & 5 & 9.5 & 11.5 & 1 & 5.0 & 6.0 & 0 & 14.5 & 17.4 & 0 \\
\hline 7 & 6 & 26.4 & 32.9 & 1 & 7.5 & 7.5 & 2 & 33.9 & 39.9 & 1 \\
\hline 8 & 9 & 1.5 & 1.0 & 0 & 1.0 & 3.0 & 6 & 2.5 & 34.9 & 0 \\
\hline & 5 & 1.5 & 1.0 & 0 & 0.2 & 0.5 & 4 & 1.7 & 1.5 & 0 \\
\hline $10 \&$ over & 22 & 3.0 & 2.5 & 0 & 1.0 & 1.0 & 10 & 4.0 & 2.5 & 0 \\
\hline Total & 57 & 6.0 & 13.0 & 2 & 2.0 & 4.0 & 27 & 8.0 & 16.5 & 1 \\
\hline F-value $\mathbf{c}$ & & 3.339 , & $\mathrm{p}<$ & 50.01 & 3.497, & $\mathrm{p}<$ & 0.005 & 3.535 , & $\mathrm{p}<$ & 0.005 \\
\hline
\end{tabular}

a Number of samples in which mercury was not detected.

b Irrorganic and organic mercury combined.

c Results of analysis of variance by gestational months. 
Table 2. Creatinine and protein concentrations in amniotic fluid.

\begin{tabular}{|c|c|c|c|c|c|c|}
\hline \multirow{2}{*}{$\begin{array}{l}\text { Gestation } \\
\text { (months) }\end{array}$} & \multicolumn{3}{|c|}{ Creatinine (n mol/l) } & \multicolumn{3}{|c|}{ Protein (g/l) } \\
\hline & Number & Mean & $\mathrm{SD}$ & Number & Mean & SD \\
\hline 4 & 3 & 62.8 & 0.9 & 3 & 5.92 & 2.14 \\
\hline 5 & 6 & 65.4 & 0.9 & 6 & 6.21 & 2.66 \\
\hline 6 & 5 & 66.3 & $-a$ & 5 & 6.04 & 1.34 \\
\hline 7 & 6 & 84.0 & 38.0 & 6 & 4.60 & 2.95 \\
\hline 8 & 7 & 77.8 & 2.7 & 9 & 5.68 & 3.88 \\
\hline & 5 & 140.6 & 15.9 & 4 & 5.00 & 2.90 \\
\hline 10 \& over & 22 & 182.1 & 28.3 & 22 & 6.54 & 5.48 \\
\hline Total & 54 & 123.8 & 57.5 & 55 & 5.96 & 4.07 \\
\hline F-value $b$ & \multicolumn{3}{|c|}{46.00 , } & \multicolumn{2}{|c|}{0.2140} & \\
\hline
\end{tabular}

a All the values were the same as the mean.

b Results of an analysis of variance by gestational months.

The mercury level did not show any significant correlation with the protein or the creatinine concentration in any gestational age group.

\section{DISCUSSION}

In the present study the amniotic fluid of most of the pregnant women contained a certain detectable amount of inorganic mercury. Organic mercury was, however, detected in about half of the amniotic fluid samples, and the mercury level was higher in its inorganic than in its organic form. Since inorganic mercury has a lower capacity for transplacental passage than organic mercury, the excess of inorganic mercury in the amniotic fluid is puzzling.

If the transplacental route is the sole route in the transfer of mercury from the mother to the fetus, most of the fetal body burden of mercury should be in the organic form. Since most of the mercury in the amniotic fluid was, however, in the inorganic form, the organic mercury reaching the fetus through the transplacental route would have to be metabolized into an inorganic form in order to be transferred to the amniotic fluid. However there is no evidence that the biotransformation of organic mercury into an inorganic form occurs in the fetus.

The exact origin of amniotic fluid is still unclear (9), but a dynamic interchange of water between the mother and fetus, the fetus and amniotic fluid, and the amniotic fluid and mother has been revealed $(4,8,10)$. The inorganic form of mercury could move with the water, and, if so, direct, rather than transplacental, transfer between mother and amniotic fluid is probable. In this connection, the accumulation of inorganic or total mercury in fetal membranes, as well as in the placenta of mice, rats or humans $(3,11,14)$, should be mentioned. Furthermore, methylmercury does not accumulate in the fetal membranes of mice (11).

It is likewise unclear why the mercury level in the amniotic fluid reaches a peak at 7 months of gestation. This occurrence may result from changes in fetal membrane function during the progress of gestation. In regard to this phenomenon, it is interesting to note that the sodium concentration of amniotic fluid follows an almost identical pattern as the mercury level (5). In addition to the possible change in the fetal membrane, the keratinization of fetal skin and the maturation of fetal kidneys, both of which start in the second half of pregnancy, may play some role in this phenomenon.

\section{ACKNOWLEDGMENT}

This study was supported by a grant from the Japanese Ministry of Education. 


\section{REFERENCES}

1. BAKIR, F., DAMLUJI, S. F., AMIN-ZAKI, L., MURTADHA, M., KHALIDI, A., ALRAWI, N. Y., TIKRITI, S., DHAHIR, H. I., CLARKSON, T. W., SMITH, J. C. and DOHERTY, R. A. Methylmercury poisoning in Iraq. Science 181 (1973) 230-241.

2. CLARKSON, T. W., MAGOS, L. and GREENWOOD, M. R. The transport of elemental mercury into foetel tissues. Biol. neonat. (Basel) 21 (1972) 239-244.

3. GARRETT, N. E., GARRETT, R. J. B. and ARCHDEACON, J. W. Placental transmission of mercury to the foetal rat. Toxicol. appl. pharmacol. 22 (1972) $649-654$.

4. HUTCHNSON, D. L., GRAY, M. L., PLENTL, A. A., ALVAREZ, H., CALDEYRO-BARCIA, R., KAPLAN, B. and LIND, J. The role of the fetus in the water exchange of the amniotic fluid of normal and hydramniotic patients. J. clin. invest. 38 (1959) $971 \longrightarrow 980$.

5. LIND, T. The biochemistry of amniotic fluid. In: D. V. I. FAIRWEATHER and T. K. A. B. ESKES (eds.), Amniotic fluid. Excerpta Medica, Amsterdam 1973, pp. $60-81$.

6. MAGOS, L. Selective atomic-absorption determination of inorganic mercury and methylmercury in undigested biological samples. Analyst 96 (1971) 847-853.

7. MANSOUR, M. M., DYER, N. C., HOFFMAN, L. H., SCHULERT, A. R. and BRILL, A. B. Maternal-foetal transfer of

Received for publication: 1976-08-09 organic and inorganic mercury via placenta and milk. Environ. res. 6 (1973) 479-484.

8. PLENTL, A. A. The dynamics of the amniotic fluid. Ann. n.y. acad. sci. 75 (1959) $746-761$.

9. SAUNDERS, P. and RHODES, P. The origin and circulation of the amniotic fluid. In; D. V. I. FAIRWEATHER and T. K. A. B. ESKES (eds.), Amniotic fluid. Excerpta Medica, Amsterdam 1973, pp. 1-18.

10. SCOGGIN, W. A., HARBERT, G. M., JR., ANSLOW, W. P., JR., VAN'T RIET, B. and MC GAUGHEY, H. S., JR. Fetomaternal exchange of water at term. Amer. j. obstet. gynecol. 90 (1964) 7-16.

11. SUZUKI, T., MATSUMOTO, N., MIYAMA, T. and KATSUNUMA, H. Placental transfer of mercuric chloride, phenyl mercury acetate and methyl mercury acetate in mice. Ind. health 5 (1967) 149-155.

12. SUZUKI, T., MIYAMA, T. and KATSUNUMA, H. Comparison of mercury contents in maternal blood, umbilical cord blood and placental tissues. Bull. environ. contam. toxicol. 5 (1971) 502-507.

13. TEJNING, S. Kvicksilverhalterna $i$ blodkroppar och $i$ blodplasma hos "normale» mødrar och deres nyfødda barn (Report 680220). Yrkesmedicinska Kliniken, Lasarettet i Lund, Sweden, 1968.

14. WANNAG, A. and SKJAERASEN, J. Mercury accumulation in placenta and foetal membranes: A study of dental workers and their babies. Environ. physiol. biochem. 5 (1975) 348-352. 